\title{
Environmental Restoration Program Waste Minimization and Pollution Prevention Awareness Program Plan
}

\author{
Environmental Restoration Division \\ P.O. Box 2003 \\ Oak Ridge, Tennessee 37831-7298
}

Date Issued-September 1991

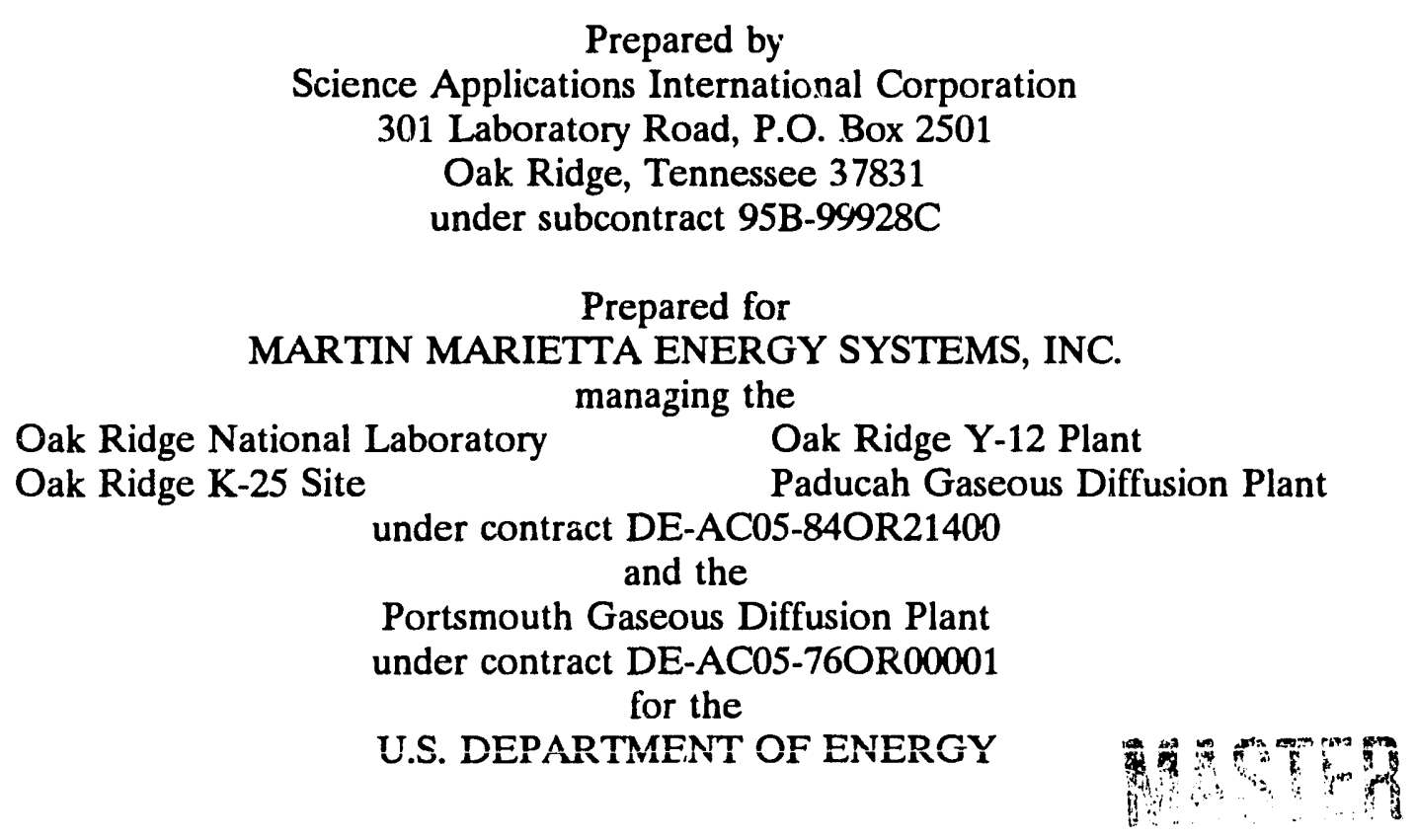


Environmental Restoration Waste

Reduction Manager: B. E. Phifer, Jr.

Environmental Restoration Waste

Programs Manager: J. T. Grumski 


\section{Environmental Restoration Program Waste Minimization and Pollution Prevention Awareness Program Plan}

September 30, 1991

Approved:

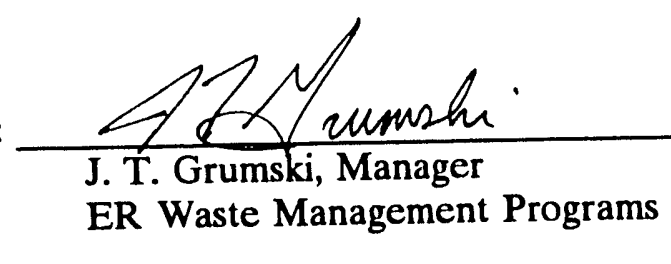

$\frac{9 / 27 / 91}{\text { Date }}$

ER Waste Management Programs

Approved:

Answat -

D. W. Swindte, Director

$\frac{9 / 30 / 91}{\text { Date }}$

Technical Integration

Approved:<smiles>CC12CCC(CC1)CC21CCCCC1</smiles><smiles>C1=CC2CCCC2C1</smiles>

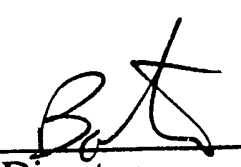

L. D. Bates, Director

ER Division

Approved:

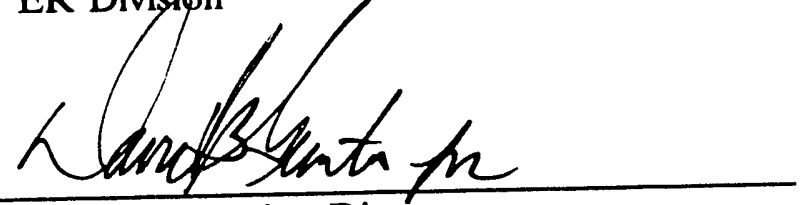

M.F.P. DeLozier, Director

Decontamination and Decommissioning Division

\section{$\frac{9 / 30 / 91}{\text { Date }}$}

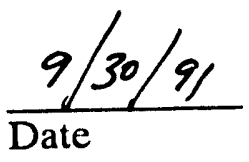

Approved:

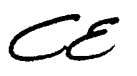

C. E. Frye, Director

Central Waste Management Division

$\frac{9 / 30 / 91}{\text { Date }}$

Approved:

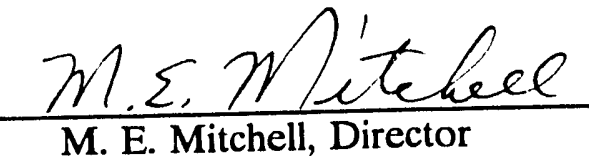

M. E. Mitchell, Director

$\frac{9-30-91}{\text { Date }}$

Compliance Evaluations and Policy 


\section{CONTENTS}

ACRONYMS $\ldots \ldots \ldots \ldots \ldots \ldots \ldots \ldots \ldots \ldots \ldots \ldots \ldots \ldots \ldots \ldots$

EXECUTTVE SUMMARY $\ldots \ldots \ldots \ldots \ldots \ldots \ldots \ldots \ldots \ldots \ldots$ vii

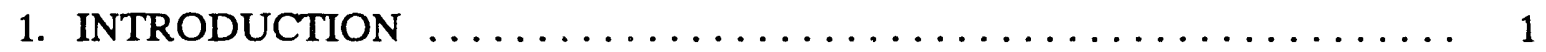

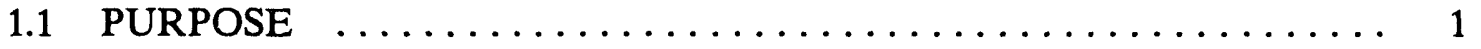

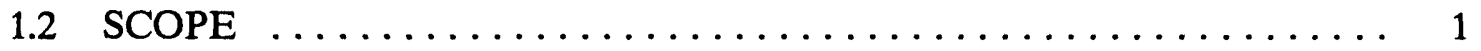

1.3 LEGAL AND POLICY BACKGROUND ............... 2

1.4 MISSION AND BACKGROUND $\ldots \ldots \ldots \ldots \ldots \ldots \ldots \ldots \ldots \ldots$

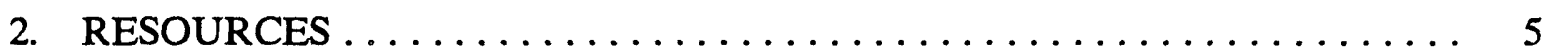

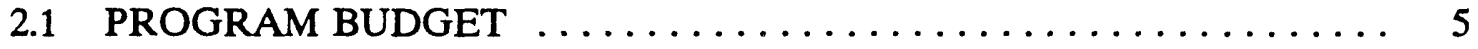

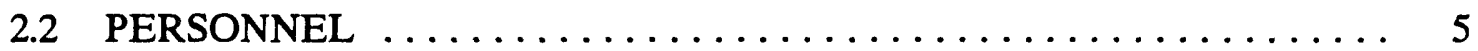

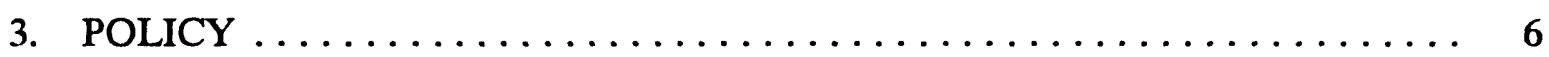

3.1 STATEMENT OF MANAGEMENT SUPPORT/COMMITMENT . . . . 6

3.2 RELEVANT SITE DIRECTIVES OR GUIDANCE ............ 6

3.3 RELEVANT ER PROGRAM DIRECTIVES OR GUIDANCE $\ldots \ldots \ldots .8$

4. STRATEGY, OBJECTIVES, AND GOALS $\ldots \ldots \ldots \ldots \ldots \ldots \ldots \ldots$

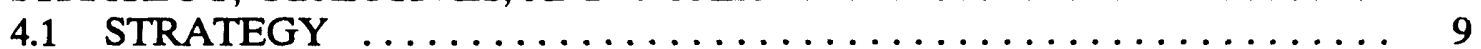

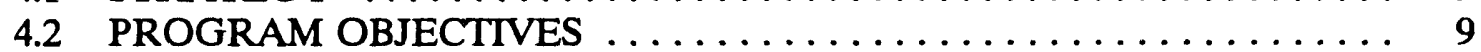

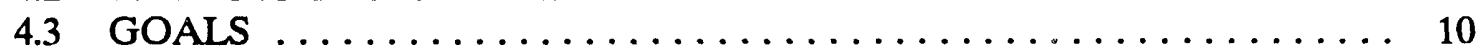

4.4 SCHEDULE OF ACTIVITIES $\ldots \ldots \ldots \ldots \ldots \ldots \ldots \ldots \ldots \ldots \ldots$

5 ORGANIZATION AND STAFF RESPONSIBILITIES $\ldots \ldots \ldots \ldots \ldots \ldots \ldots$

5.1 DESCRIPTION OF WASTE MINIMIZATION ORGANIZATION $\ldots \ldots$.

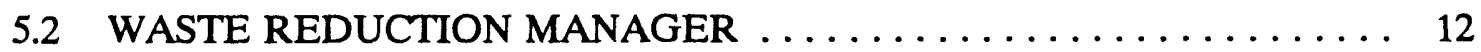

5.3 WASTE REDUCTION SITE REPRESENTATIVES $\ldots \ldots \ldots \ldots \ldots \ldots$

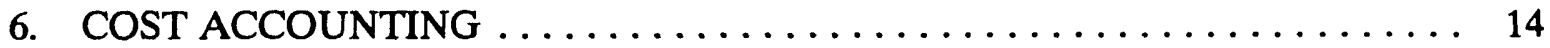

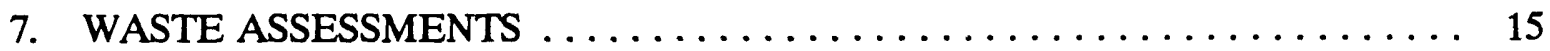

8. WASTE MINIMIZATION/POLLUTION PREVENTION TECHNIQUES $\ldots . .16$

9. TRAINING, AWARENESS, AND INCENTIVES $\ldots \ldots \ldots \ldots \ldots \ldots \ldots \ldots$

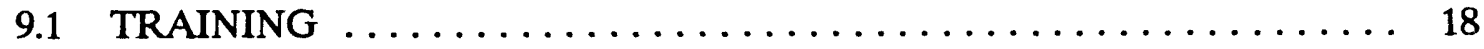

9.2 EMPLOYEE ORIENTATION PROGRAM $\ldots \ldots \ldots \ldots \ldots \ldots \ldots \ldots$

9.3 ER SPECIALIZED TRAINING PROGRAM $\ldots \ldots \ldots \ldots \ldots \ldots \ldots \ldots$

9.4 PROCEDURES QUALIFICATION $\ldots \ldots \ldots \ldots \ldots \ldots \ldots \ldots \ldots \ldots \ldots$

9.5 PERFORMANCE EVALUATIONS ................... 19

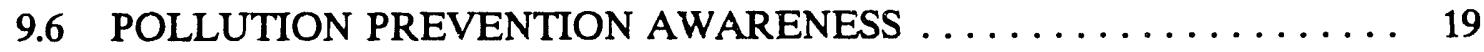

9.7 INCENTIVE AWARDS AND RECOGNITION $\ldots \ldots \ldots \ldots \ldots \ldots \ldots .20$ 
10. TRACKING AND REPORTING SYSTEMS $\ldots \ldots \ldots \ldots \ldots \ldots \ldots \ldots \ldots$

10.1 TRACKING FROM POINT OF GENERATION TO POINT OF FINAL DELIVERY TO THE SITE WASTE MANAGEMENT ORGANIZATIONS $\ldots \ldots \ldots \ldots \ldots \ldots \ldots \ldots \ldots \ldots$

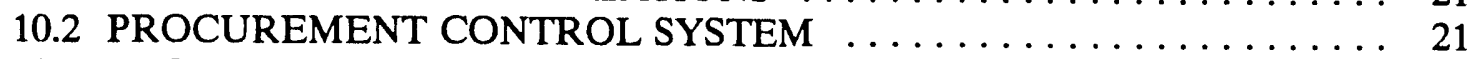

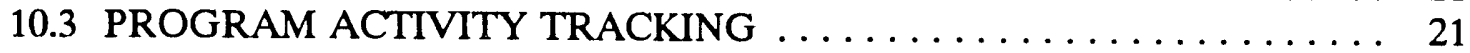

10.4 FEDERAL AND STATE REPORTING REQUIREMENTS $\ldots \ldots \ldots \ldots .22$

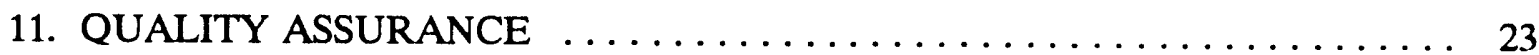

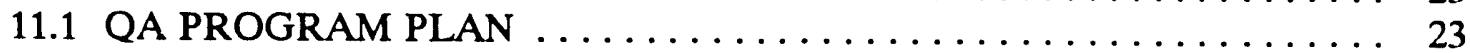

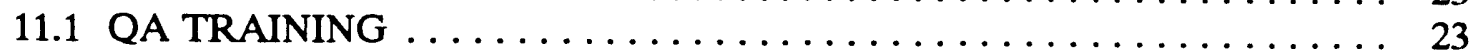

12. INFORMATION EXCHANGE AND OUTREACH $\ldots \ldots \ldots \ldots \ldots \ldots \ldots$

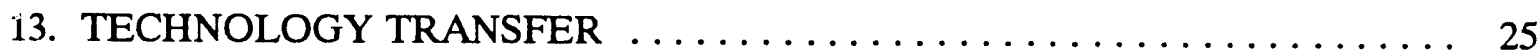

14. RESEARCH AND DEVELOPMENT $\ldots \ldots \ldots \ldots \ldots \ldots \ldots \ldots \ldots$

15. PROGRAM EVALUATION $\ldots \ldots \ldots \ldots \ldots \ldots \ldots \ldots \ldots \ldots \ldots \ldots \ldots$

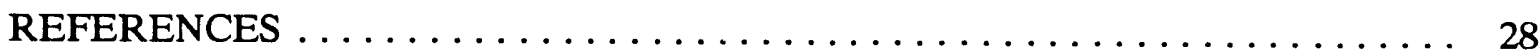

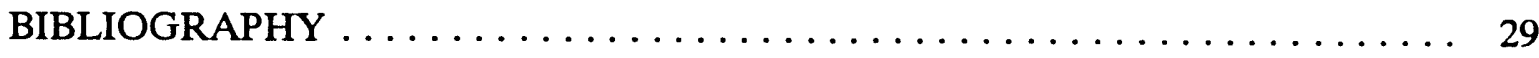

Appendix A. WASTE MINIMIZATION AND POLLUTION PREVENTION

AWARENESS PROGRAM BUDGET $\ldots \ldots \ldots \ldots \ldots \ldots \ldots \ldots \ldots \ldots$

Appendix B. ENVIRONMENTAL RESTORATION PP.OGRAM

WASTE MINIMIZATION POLICY $\ldots \ldots \ldots \ldots \ldots \ldots \ldots \ldots \ldots \ldots \ldots$

Appendix C. IMPLEMENTATION SCHEDULE FOR WASTE

MINIMIZATION AND POLLUTION PREVENTION

AWARENESS PROGRAM ACTIVITIES .................. 39

Appendix D. ORGANIZATIONAL CHART $\ldots \ldots \ldots \ldots \ldots \ldots \ldots \ldots \ldots$ 


\section{ACRONYMS}

$\begin{array}{ll}\text { CEP } & \text { Compliance Evaluations and Policy } \\ \text { CWMD } & \text { Central Waste Management Division } \\ \text { D\&D } & \text { Decontamination and Decommissioning } \\ \text { DOE } & \text { Department of Energy } \\ \text { DOE-OR } & \text { Department of Energy Field Office, Oak Ridge } \\ \text { EPA } & \text { Environmental Protection Agency } \\ \text { ER } & \text { Environmental Restoration } \\ \text { HSWA } & \text { Hazardous and Solid Waste Amendments } \\ \text { ORR } & \text { Oak Ridge Reservation } \\ \text { QA } & \text { quality assurance } \\ \text { R\&D } & \text { research and development } \\ \text { RA } & \text { Remedial Action } \\ \text { RCRA } & \text { Resource Conservation and Recovery Act } \\ \text { RDDT\&E } & \text { Research, Development, Demonstration, Testing, and Evaluation } \\ \text { TD\&A } & \text { Technology Development and Applications Program } \\ \text { TSCA } & \text { Toxic Substances Control Act } \\ \text { WMPPAP } & \text { Waste Minimization and Pollution Prevention Awareness Program } \\ \text { WRSR } & \text { waste reduction site representatives }\end{array}$




\section{EXECUTIVE SUMMARY}

In response to DOE Order 5400.1 this plan outlines the requirements for a Waste Minimization and Pollution Prevention Awareness Program for the Environmental Restoration (ER) Program at Martin Marietta Energy Systems, Inc. Statements of the national, Department of Energy, Energy Systems, and Energy Systems ER Program policies on waste minimization are included and reflect the attitudes of these organizations and their commitment to the waste minimization effort. Organizational responsibilities for the waste minimization effort are clearly defined and discussed, and the program objectives and goals are set forth. Waste assessment is addressed as being a key element in developing the waste generation baseline. There are discussions on the scope of ER-specific waste minimization techniques and approaches to employee awareness and training. There is also a discussion on the process for continual evaluation of the Waste Minimization Program. Appendixes present an implementation schedule for the Waste Minimization and Pollution Prevention Program, the program budget, an organization chart, and the ER waste minimization policy. 


\section{INTRODUCTION}

\subsection{PURPOSE}

This plan outlines the establishment of a Waste Minimization and Pollution Prevention Awareness Program (WMPPAP) for the Martin Marietta Energy Systems, Inc., Environmental Restoration (ER) Program. This plan will establish the program requirements for managers, operations personnel, and support staff for waste minimization for all Remedial Action (RA) and Decontamination and Decommissioning (D\&D) activities. The plan identifies activities and methods that will be employed to reduce the quantity and toxicity of wastes generated by the ER Program. It is intended to satisfy Department of Energy (DOE) and other legal requirements as discussed in Sect. 1.3. The Pollution Prevention Awareness Program is included with the Waste Minimization Program as provided by DOE Order 5400.1, "General Environmental Protection Program."

\subsection{SCOPE}

The WMPPAP establishes an organized, comprehensive, and continual effort to systematically reduce the generation of waste. The WMPPAP is also designed as an ongoing effort to systematically eliminate or minimize pollutant releases to environmental media from all aspects of the ER Program's operations, thereby enhancing protection of public health and the environment. Additional benefits of this program include reduced waste management and compliance costs, reduced resource usage, improved waste management, reduced or eliminated inventories and releases of hazardous chemicals reportable under the Emergency Planning and Community Right-to-Know Act, reduced or eliminated civil and criminal liabilities under environmental laws, and improved public image.

The progran reflects the goals and policies for waste minimization of this organization and represents an ongoing effort to make pollution prevention/waste minimization part of the ER Program operating philosophy. In accordance with DOE policy, a hierarchical approach to waste reduction has been adopted and is applied to all types of waste.

Waste will be minimized by focusing on source reduction or recycling activities that reduce the volume or the toxicity of hazardous waste generated. Those potential waste materials that cannot be eliminated or minimized will be recycled (i.e., used, reused, or reclaimed). All waste that is nevertheless generated will be treated, if technology exists, to reduce volume, toxicity, or mobility before storage or disposal.

Various waste minimization techniques will be implemented with the support of employee training and awareness programs to reduce waste and still meet the requirements for quality, productivity, safety, and environmental compliance.

Primary elements of the plan include policy, budget, strategy, objectives, goals, organization and staff responsibilities, cost accounting, waste assessments, waste minimization techniques, training, technology transfer, implementation schedule of program activities, and 
a process for continual evaluation of the program. It provides guidance to ER Program contractors and site operation users in preparing individual waste minimization and pollution prevention awareness implementation program plans.

This plan applies to all ER Program site activities and associated support operations. Requirements for site contractors are discussed in Chap. 5. Once implemented, this plan will be reviewed annually and revised as necessary. At a minimum, the plan will be updated every 3 years. The policy, goals, objectives, and strategy of the plan will be explained to all ER Program employees, and distribution will be made to the affected employees and site contractors.

This plan has been distributed to affected employees and site contractors. The policy, goals, objectives, and strategy of the plan have been explained to all employees.

\subsection{LEGAL AND POLICY BACKGROUND}

The Resource Conservation and Recovery Act (RCRA) requires hazardous waste generators to establish a program to reduce the volume or toxicity of waste to the degree determined by the generator to be "economically practicable." Hazardous waste generators must certify in their waste manifest that they have fulfilled this requirement. Generators must also identify, in their biennial reports to the Environmental Protection Agency (EPA) or the appropriate state, their efforts during the year to reduce the volume and toxicity of waste they generated and the changes in volume and toxicity they actually achieved. Waste generators also have the option to report waste minimization results when they submit their annual toxic chemical release inventories to EPA.

DOE Orders 5400.1, 5400.3, and 5820.2A mandate that radioactive wastes and other pollutants shall be managed to minimize the generation of such wastes.

DOE Order 5400.1 (ref. 1) establishes environmental protection program requirements and responsibilities for ensuring compliance with environmental protection laws. The order requires the establishment of a waste minimization program "that will contain goals for minimizing the volume and toxicity of all wastes that are generated" and a Pollution Prevention Awareness Program. The Waste Minimization Program and the Pollution Prevention Awareness Programs are to be estaulished through implementing plans. The implementing guidance permits consolidation of the two programs and implementing plans.

DOE Order 5400.3, "Hazardous and Radioactive Mixed Waste Program,"2 establishes DOE hazardous and radioactive mixed waste policies and requirements and implements the requirements of RCRA within the framework of the environmental programs established under DOE Order 5400.1. The order states that it is DOE policy to "implement waste minimization measures as specified in RCRA for hazardous and radioactive mixed wastes." DOE Order 5400.1 requires the heads of field organizations to "implement a waste minimization program for haza.rdous and radioactive mixed wastes."

DOE Order 5820.2A, "Radioactive Waste Management,"3 establishes policies, guidelines, and minimum requirements by which DOE manages its radioactive and mixed waste and contaminated facilities. It states that the "generation, treatment, storage, transportation, 
and/or disposal of radioactive wastes, and the other pollutants or hazardous substances they contain, shall be accomplished in a manner that minimizes the generation of such wastes across program office functions and complies with all applicable federal, state, and local environmental, safety, and health laws and regulations and DOE requirements." The order requires the preparation of a waste management plan for each site that generates, treats, stores, or disposes of DOE wastes. The elements of the waste management plan are incorporated into the project-specific plan, which "will indicate actions to minimize hazardous waste generation" as specified in the order.

DOE Order 5820.2A contains specific waste minimization requirements for management of high-level, transuranic, and low-level waste. These requirements include process modification, process optimization, and materials substitution.

DOE's waste reduction policy ${ }^{4}$ requires all DOE program offices and field operations to "institute a waste reduction policy to reduce the total amount of waste that is generated and disposed of by DOE operating facilities through waste minimization (source reduction and recycling) and waste treatment." The policy consolidates the requirements of DOE Orders $5400.1,5400.3$, and $5820.2 \mathrm{~A}$ for either a waste minimization or a waste reduction plan and attaches guidance for satisfying the reporting requirements of those orders. The statement adopts the hierarchical approach to waste reduction and applies the policy to all types of waste. The policy requires waste reduction to be a "prime consideration" in research activities, process design, and facility design and operations.

\subsection{MISSION AND BACKGROUND}

Energy Systems, as a prime contractor, manages five installations for DOE Field Office, Oak Ridge (DOE-OR): the Oak Ridge K-25 Site, the Oak Ridge National Laboratory, and the Oak Ridge Y-12 Plant on the Oak Ridge Reservation (ORR) in Oak Ridge, Tennessee; the Paducah Gaseous Diffusion Plant in Paducah, Kentucky; and the Portsmouth Gaseous Diffusion Plant in Piketon, Ohio. In pursuit of its own historical mission, each facility has created contaminated sites that are now under investigation. The ER Program is responsible for investigating and cleaning up these sites, as well as off-site ORR locations, while minimizing the threat to human health and the environment.

The ER Program will conduct RA and D\&D at over 500 contaminated sites on the DOE-OR facilities in Oak Ridge, Paducah, and Piketon. As part of this mission, the ER Program will generate wastes from a variety of activities, including:

- Site characterization

- Site remediation

- Routine maintenance and surveillance of facilities

- Decontamination of facilities and equipment

- Dismantling of facilities and removing equipment

- Treatment of contaminated soil and water

- Removal of contaminated materials for storage/disposal

- Construction of containment systems in contaminated areas

- Demonstration of viable remediation and D\&D technologies 
While the exact volume of waste cannot yet be accurately forecast, early indications and estimates are th at these volumes will be significant (millions of cubic feet of material). Hence, early and structured application of waste reduction and pollution prevention programs can have a tremendous positive impact.

Management of the ER Program activities for the installations that Energy Systems operates rests with DOE-OR. The DOE-OR ER Program reports to the Office of Environmental Restoration and Waste Management at DOE Headquarters.

The waste materials generated by the ER Program will be carefully controlled in accordance with federal, state, and local agency regulations. The intent of this plan is to respond to and comply with DOE's policy and guidelines concerning the need for pollution prevention. 


\section{RESOURCES}

\subsection{PROGRAM BUDGET}

Appendix A presents the budget for WMPPAP and reflects the distribution of funds allocated to waste reduction program activity from FY 1992 through FY 1996.

\section{PERSONNEL}

The planning and oversight staff for the WMPPAP will require a 1.5 work-year commitment. This estimate includes a waste reduction manager, waste reduction site representatives (WRSRs), part-time technical staff, and subcontractor support. 


\section{POLICY}

\subsection{STATEMENT OF MANAGEMENT SUPPORT/COMMITMENT}

Energy Systems senior management is dedicated to protesting and preserving the environment and public health through numerous programs, activities, and operations. Key elements of the Energy Systems role as managing contractor for the DOE facilities at the Oak Ridge Field Office are the RA and D\&D programs. Waste management has a very high priority within these programs. As a part of waste management planning, the ER Program is developing a aste minimization plan to reduce the amount of waste generated by RA and D\&D prugrams.

ER management is firmly committed to waste minimization and pollution prevention and fully supports efforts directed at its implementation. Specifically, ER establishes, through this plan, its WMPPAP and has required ER Program contractors and the site users to prepare WMPPAP implementation program plans. These plans, when prepared, will follow the format and guidance established in this document. The implementation program plans will contain a written policy implementing recommendations identified through assessments, evaluations, or other means. Specifically,

1. contractors and site users shall ensure that implementation program plans are in accordance with applicable federal, state, and local environmental laws, regulations, and DOPE orders, and

2. contractors and site users shall develop internal guidance and instructions consistent with this overall ER policy, which will be included in their respective implementation plans.

The ER Program Waste Management Programs manager and the management team are totally committed to minimizing the generation of waste by giving preference to cleanup plan reviews, project waste management plan reviews, and ER-specific waste minimization techniques over treatment, storage, and disposal of such wastes. Top management will provide adequate personnel, budget, training, and material on a continuing basis to ensure that WMPPAP meets its objectives.

\subsection{RELEVANT SITE DIRECTIVES OR GUIDANCE}

The follcwing government policies and DOE orders govern the implementation of this plan and provide additional guidance.

\subsubsection{National Waste Minimization Policy}

A national policy to reduce or eliminate generation of hazardous waste was initiated with passage of the 1984 Hazardous and Solid Waste Amendments to RCRA:

The Congress hereby declares it to be the national policy of the United States that, wherever feasible, the generation of hazardous wastes is to be reduced or eliminated as expeditiously as possible. Waste that is nevertheless generated should 
be treated, sorted, or disposed of so as to minimize the present and future threat to human health and the environment.

This amendment requires that the waste generator establish a program to reduce the volume and toxicity of waste generated to an economically practicable degree.

\subsection{DOE Waste Minimization Policy and Regulation}

DOE-OR requires Energy Systems to meet waste minimization criteria as part of its award fee contract. DOE policy and regulation are reflected in the following DOE orders.

DOE Order 5400.1 (ref. 1) requires development of a waste minimization program plan. Each DOE operating facility is required to

- Develop a waste minimization program plan, review the plan annually, revise as needed, and update every 3 years

- Develop goals for minimizing the volume and toxicity of all nonhazardous solid waste and all hazardous, radioactive, and radioactive mixed waste generated, aiming for annual reductions if programmatic requirements allow

- Track and compare annual changes in waste volume and toxicity

- Identify and report on proposed waste minimization techniques that are technically and economically practicable

DOE Order 5400.3 (ref. 2) states that it is the policy of DOE to "implement waste minimization measures as specified in RCRA for hazardous and radioactive mixed wastes."

DOE Order 5820.2A contains provisions for waste reduction for each of the waste categories: high-level, transuranic, and low-level wastes. With regard to waste generation, IJOE Order 5820.2A Sect. III.3.c. states: ${ }^{3}$

Technical and administrative controls shall be directed to reducing the gross volume of waste generated and/or the amount of radioactivity requiring disposal. Waste reduction efforts shall include consideration of process modification, process optimization, materials substitution, and decontam nation.

All DOE low-level waste generators shall establish auditable programs (goals, incentives, procedures, and reports) to assure that the amount of low-level waste generated and/or shipped for disposal is minimized.

Each DOE low-level waste generator shall separate uncontaminated waste from lowlevel waste to facilitate cost effective treatment and uisposal.

Each DOE low-level waste generator preparing a design for a new process or process change shall incorporate principles into the design that will minimize the generation of low-level waste. 
With regard to waste treatment, DOE Order 5820.2A Sect. III.3.f. states: ${ }^{3}$

Waste treatment techniques such as incineration, shredding, and compaction to reduce volume and provide more stable waste forms shall be implemented as necessary to meet performance requirements.

\subsection{Energy Systems Waste Minimization Policy}

The Energy Systems waste minimization policy statement ${ }^{5}$ was framed in May 1986:

It is the policy within Energy Systems to minimize the generation of hazardous waste, mixed hazardous waste, and low-level radioactive waste from all activities.

The preferred avenues for achieving waste minimization or reduction are process elimination, optimization, or change; material substitution; recycling; reuse; sale; or energy recovery. For residual wastes that may not be amenable to the preceding methods, the goal for waste disposition is use of the most cost-effective method that protects human health and the environment. Cost-effectiveness and environmental worthiness must be evaluated with regard to long-term potential liabilities as well as immediate cost considerations.

\subsection{ER Program Waste Minimization Policy Statement}

ER Program management support of the WMPPAP is evidenced by the following waste minimization policy statement declarations:

- The ER Program shall employ the most cost-effective and environmentally accepiable methods to manage and minimize the generation of waste.

- The ER Program shall demonstrate its commitment to WMPPAP by conducting waste management activities to accomplish site cleanup and waste minimization through project waste management plan reviews, RA and D\&D waste segregation/contamination zone controls, closure reviews, field controls, and field treatment of wastes.

The ER Program Waste Management Programs manager has drafted a written policy establishing the WMPPAP and stating a waste minimization policy for the ER Program. This policy is currently undergoing formal approval and issuance. The policy can be found in Appendix B.

\subsection{RELEVANT ER PROGRAM DIRECTIVES OR GUIDANCE}

Detailed ER Program standard policies and guidelines to govern the implementation of this plan and provide additional guidance will be developed by the end of FY 1992.

The ER Program will also be responsible for administering the guidance, instructions, and guidelines applicable to the operations of any subcontractors temporarily working on site. 


\section{STRATEGY, OBJECTIVES, AND GOALS}

\subsection{STRATEGY}

A waste minimization program is being developed to obtain accurate and current information on waste stream generation and waste management costs. This information will provide the basis for the implementation of specific waste minimization techniques and technologies. The program will develop procedures for collecting information, evaluating options, and identifying cost-effective waste minimization techniques. The essential elements of the strategy follow.

- Provide WMPPAP and programmatic goals

- Obtain waste generation rate forecasts

- Establish a waste generation baseline

- Perform waste assessments

- Evaluate waste reduction methods and technologies

- Set numerical waste reduction goals

- Institute employee training and awareness programs

- Achieve waste reduction

\subsection{PROGRAM OBJECTIVES}

The objectives of the WMPPAP are to

- Foster a philosophy to conserve resources and raw materials to minimize waste

- Promote the use of nonhazardous materials in ER program operations to minimize the potential risks to human health and the environment

- Reduce or eliminate the generation of waste materials from D\&D and RA activities through input substitution; product reformulation; process modification; improved housekeeping; reuse of facilities and materials; and on-site, closed-loop recycling to minimize adverse effects on the air, water, and land

- Enhance communication of waste minimization objectives, goals, and ideas laterally and vertically among site organizations

- Promote integration and coordination of waste generators and waste managers on waste minimization matters

- Characterize waste streams and develop a baseline of waste generation data

- Identify and implement waste reduction methods and technologies for RA and D\&D program activities

- Target policies, procedures, or practices that may be barriers to waste minimization

- Create incentives that reward employees who identify opportunities for waste minimization 
- Develop and implement employee waste minimization and pollution prevention awareness training programs that are specific to ER

- Collect and exchange waste minimization information through technology transfer, outreach, educational networks, and the publication of success stories

- Develop mechanisms for fully disseminating current technical information to site users

- Enhance employee awareness of pollution prevention goals, objectives, and methods

- Develop specific programmatic goals and schedules for waste minimization activities

- Comply with federal and state regulations and DOE requirements for waste minimization

\subsection{GOALS}

The ER Program has completed waste generation rate forecasts for RA and D\&D activities to be used to establish a waste generation baseline. Until that baseline is established, development of meaningful numerical waste minimization goals is limited. Work is currently in progress to prepare a set of bounding estimates of the waste generated by ER Program activities over the next 5 years. Goals shall be reevaluated annually and shall reflect any changes in program activities. Contractor and site user goals should reflect the ER Program goals and be structured, within inherent operating-level constraints, to facilitate their attainment. Programmatic waste minimization and Pollution Prevention Awareness Program activities and their schedule are listed in Appendix C. Additional ER goals are as follows.

- To characterize waste streams and maintain a baseline of waste generation data

- To develop numerical goals for the ER waste reduction program in CY 1992.

- To promote the use of nonhazardous materials in ER to minimize the potential risks to human health and the environment.

- To implement the recycling of paper in ER during CY 1991

- To identify and implement alternative treatment technologies and waste reduction methods

- To incorporate waste minimization concepts and technologies in planning and designing of new production processes and new facilities and in upgrading existing facilities

- To create and implement an ER employee awareness and training program for waste minimization and pollution prevention awareness

- To develop and implement an ER waste tracking system

\subsection{SCHEDULE OF ACTIVITIES}

The implementation schedule of program activities for the ER Program WMPPAP Plan can be found in Appendix C. 


\section{ORGANIZATION AND STAFF RESPONSIBILITIES}

\subsection{DESCRIPTION OF WASTE MINIMIZATION ORGANIZATION}

The Energy Systems ER Dirision is the integrating organization for the DOE-OR ER Program and as such shall be responsible for establishing waste minimization and pollution prevention goals. The DOE prime contractors (Energy Systems, the DOE-OR Technical Support Contractor, the DOE-OR Environmental Support Contractor, and the DOE-OR Construction Manager) also shall be responsible for establishing and implementing waste minimization requir ements for their portions of ER Program activities. The ER Division shall coordinate and ensure program consistency among the program participants. The Energy Systems Central Waste Management Division (CWMD) and the Energy Systems Compliance Evaluations and Policy (CEP) Division shall review waste minimization goals, approve waste minimization plans, and oversee implementation of the plans. The assistant manager for Environment, Safety, and Quality and the DOE-OR ER Division is accountable for waste minimization and shall review and oversee waste minimization activities. Specific interfaces between the DOE prime contractors and their roles in ER and waste management activities relative to waste minimization is documented as part of the integrating contractor Memorandum of Understanding. See Appendix D for the complete organizational structure.

Energy Systems organizations with implementation responsibilities follow.

The ER Division is responsible for ensuring that all generator requirements for both waste minimization and waste reduction are met. To meet these requirements, the ER Division has identified a Waste Programs Management Department within its Technical Integration Program Office. The ER waste programs manager is responsible for developing a Waste Reduction Program for ER Program activities and has appointed the ER Program waste reduction manager (see Sect. 5.2). This manager will also be responsible for ensuring that the ER Program waste reduction program complies with all Energy Systems internal requirements and is coordinated with CWMD, the CEP Division, and the WRSRs (see Sect. 5.3) as appropriate.

Prime contractors (i.e., Radian Corporation, Ebasco Services, Science Applications International Corporation, and M-K Ferguson) are responsible for complying with all federal, state, and local regulations and requirements outlined in the WMPPAP and incorporating the requirements outlined in the WMPPAP in all subcontractor-developed work plans and procedures.

CWMD is responsible for (1) ensuring that each hazardous waste generator has in place a waste minimization program which includes coordination with an Energy Systems-wide waste reduction and minimization program, (2) approval of the ER WMPPAP, (3) review of ER waste minimization goals, and (4) auditing and documenting the overall performance of the waste minimization program.

The CEP Division is responsible for (1) overall guidance on policy and procedures for waste minimization activities, (2) approval of the ER WMPPAP, and (3) review of ER waste minimization goals.

The Energy Systems Engineering Organization is responsible for developing and incorporating the requirements outlined in the WMPPAP into all specifications and design drawings. 
The ER Division Technology Development and Applications (TD\&A) Program manager is responsible for implementing a technology transfer effort to collect lessons learned about waste reduction technologies used and for distributing this information within the ER Program. The manager of the TD\&A program is responsible for interactions with the site demonstration program managers who are responsible for the day-to-day management of technology demonstrations.

The ER Quality Assurance manager is responsible for overall guidance on policy and procedures for quality assurance for waste minimization activities.

The ER Health and Safety manager is responsible for assisting in the development of training for waste minimization and pollution prevention awareness activities.

The program organizational structure shown in Appendix $D$ is designed to maximize the dissemination and collection of waste minimization information and pruvide waste generating organizations with managerial responsibility for the development, design, construction, and implementation of waste minimization projects.

\subsection{WASTE REDUCTION MANAGER}

The ER Program waste reduction manager will manage and integrate the WMPPAP to ensure that all ER Program waste generators approach and conduct their tasks of waste reduction in a technically consistent and operationally similar maruner. The ER Program waste reduction manager shall be responsible for preparing and updating the program waste minimization plan and for establishing annual waste minimization objectives. This manager will meet quarterly with the WRSRs to exchange information, provide updates on waste reduction developments, elicit suggestions and ideas, discuss problem areas, and review the waste minimization program. This will serve as the equivalent to the waste minimization committee as outlined in the model plan. Also, this manager has the following responsibilities.

- Develop standardized waste reduction checklist

- Review project waste management plans using criteria from a standardized waste reduction checklist

- Review the waste minimization section in all cleanup plans

- Develop document and implement employee training and pollution prevention awareness

- Implement incentive programs

- Track progress toward goals

- Publish the ER waste reduction and pollution prevention awareness quarterly newsletter

- Submit and conduct the midyear review of the waste minimization budget

- Issue guidance and review site and contractor WMPPAP implementation program plans

- Develop and implement waste tracking and reporting systems

- Review the preparation of and submit (1) site and contractor annual waste reduction reports, (2) the ER annual waste reduction report, and (3) the biennial waste reduction report

- Represent ER on all matters pertaining to the waste reduction program 
- Develop, document, and conduct the waste minimization waste assessments, surveillances, and evaluations

- Summarize all existing technologies for waste treatment alternatives and identify new technologies

\subsection{WASTE REDUCTION SITE REPRESENTATIVES}

The WRSRs for the ER Program act as program coordinators for waste reduction activities at their respective sites. The primary functions of the WRSRs are to provide awareness of WMPPAP, identify tasks to implement the program, and provide a mechanism for communication within their sites on waste minimization matters.

The responsibilities of the WRSRs include

- Communicating waste minimization program objectives to the sites

- Obtaining waste generator support and input for the program

- Obtaining all information necessary for the preparation of site and contractor annual waste reduction reports

- Ensuring that new projects or changes to existing facilities include consideration of waste reduction in design or construction, using criteria from a standardized waste reduction checklist

- Promoting ongoing employee awareness and training

- Participating in waste assessments, surveillances, and evaluation

- Coordinating the preparation of and implementing the site and contractor WMPPAP implementation plans

- Monitoring and reporting progress of the waste minimization program through quarterly reviews and workshops

- Recommending personnel for achievement and incentive awards

- Submitting site-specific waste reduction ideas, problems, or nominations

The WRSR position is not a full-time position; employees and subcontractors acting in these roles have other responsibilities. 


\section{COST ACCOUNTING}

The existing accounting system will be used to account for the cost of the waste generated by a project and to permit meaningful reviews and audits. The existing system will account for the short- and long-term costs of managing and disposing of the wastes. Associated costs will include personnel, record keeping, transportation (including on-site capital equipment movement), pollution control equipment, treatment, storage, and disposal costs. The costs taken from the existing accounting system will be included in proposals, planning, and budgeting. 


\section{WASTE ASSESSMENTS}

Waste assessments will be conducted as part of an ongoing program to identify, screen, and analyze options to reduce the creation of waste. A waste assessment determines the amount of material to be disposed of as waste during RA and D\&D operations at a specific site. It provides a summary of hazardous materials usage and waste generation and identifies those activities that need to be improved or replaced to promote waste minimization. The assessment provides a basis for prioritizing the specific modifications to site activities or other waste minimization options developed during the assessment.

Waste assessments will be accomplished by project teams. These teams will assess all waste-generating operations from RA and D\&D activities. The champion of each project team will be familiar with the ER Program RA and D\&D work and waste management operations and will possess proven technical and problem-solving abilities. The project teams will be coordinated by the ER waste reduction manager. The remainder of each project t:am will be drawn from staff or subcontractor organizations who can furnish the specialized expertise that will be needed to conduct the assessment.

Each project team will consist of a small core of individuals familiar with the ER Program RA and D\&D operations who will direct the focus of the assessment efforts and guide the data gathering. Other persornel furnishing $s_{i}$,ecialized expertise will be used on a part-time basis as the need for particular expertise occurs. Each team will include members who have knowledge in the following areas:

- Federal, state, and local hazardous waste statutes and regulations

- Production and waste minimization principles and techniques

- Quality control requirements

- Purchasing and material control/inventory

Each project team will develop flow sheets, process descriptions, and waste stream characterizations for the assigned assessment area.

Waste minimization techniques will be considered before the start of a project in the task-specific waste management plan. Each project waste management plan will be reviewed by the ER waste reduction manager who will review the management plans using criteria from a standardized waste reduction checklist.

Waste minimization opportunities will be evaluated and identified with specific projects, which when implemented will reduce the vol 1 me and toxicity of the waste streams. Each team will repo:t the data and findings from its assessment and recommend options for waste minimization. In identifying waste minimization options, the project teams will concentrate first on source reduction options, followed by recycling and treatment technologies. The project teams will identify those opportunities that deserve careful evaluation. The results of the screening process will be a list of options that are candidates for technical and economic evaluation. 


\section{WASTE MINIMIZATION/POLLUTION PREVENTION TECHNIQUES}

Waste minimization focuses on source reduction or recycling activities that reduce either the volume or the toxicity of hazardous waste generated. Pollution prevention is a multimediafocused methor that centers on preventing the generation of wastes as part of daily operations instead of treating them after they are generated. EPA considers source reduction and recycling to be viable waste minimization techniques. The EPA hierarchy of waste management methods is as follows.

- Source reduction. The reduction or elimination of waste at the source, usually within a process operation.

- Recycling. The use or reuse of hazardous waste as an effective substitute for a commercial product or feed in a process.

- Treatment. Any activity that makes the hazardous waste more amenable for disposal (e.g., reduces volume or toxicity).

- Disposal. The discharge, deposit, injection, dumping, spilling, leaking, or placing of hazardous waste into or on any land or water so that such waste or any constituent may enter the air or be discharged into any waters, including groundwater.

ER activities differ significantly from routine plant operations. While the focus for waste minimization for operating plants is often on source reduction and/or recycling, those techniques are not as applicable to ER projects, where ongoing process operations generally do not exist. Although EPA ranks treatment as its least preferred waste management alternative, technology demonstration projects to facilitate viable waste reduction treatment options will be pursued by ER. Treatment is consistent with waste minimization's basic intent to protect human health and the environment by reducing volume and/or toxicity of a waste.

The single greatest impact on ER waste minimization will be selection of the cleanup option for remediation at a site. To be sure that waste minimization is considered in these decisions, all cleanup plans will include a section on waste minimization and all plans will be reviewed by the ER waste reduction manager as part of the technical review of the project. Remediation options and application of waste minimization technologies will be the focus of this review. Recommendations by the waste reduction manager must be formally responded to by the remediation team. Also, for ER projects, up-front waste minimization planning can be incorporated into the design and construction of closure treatment facilities. Therefore, the waste reduction program focus is generally on review of closure plans and project waste management plans, where early input can have the largest impact. However, there are ERspecific waste minimization techniques that will routinely be employed in the various phases of the program and for which project-specific procedures are developed as part of the waste management plans. A brief overview of these techniques follows, presented according to ER program phase. 
Remedial Investigations

- Evaluation of sampling procedures to determine if waste can be reduced

- Segregation of waste at the source (i.e., drill cuttings and well development waters)

- Establishment and strict maintenance of contamination zones

- Proper selection and management of protective clothing

- In-field pretreatment of wastes (i.e., decontamination, compaction, and dewatering)

- Maintenance of strict housekeeping requirements to minimize potential for cross contamination

\section{Closure Activities}

- Segregation of waste by depth and typa,

- Establishment and strict maintenance of contamination zones

- Proper selection and management of protective clothing

- In-field treatment of wastes (i.e., decontamination, compaction, and dewatering)

- Proper selection of earth-moving equipment to minimize excavation of uncontaminated material

- Implementation of new waste reduction methods and technologies

- Closure monitoring of closure progress against objectives to minimize removal volumes

- Proper containment of wastes removed (i.e., tanks, drums, and lined waste piles)

- Maintenance of strict liousekeeping requirements to minimize potential for cross contamination

Facilities, Maintenance, and Surveillance

- Reuse of facilities

- Establishment and strict maintenance of contamination zones

- Proper segregation of routine wastes

- Maintenance of containment and segregation of stored wastes

- In-facility pretreatment of wastes (i.e., filter compaction, filter sludge dewatering)

- Implementation of new waste reduction methods and technologies

- Maintenance of strict housekeeping requirements to minimize potential for cross contamination 


\section{TRAINING, AWARENESS, AND INCENTIVES}

The Pollution Prevention Awareness Program required by DOE Order 5400.1 (ref. 1) has been incorporated with the Waste Minimization Program. The purpose of the Pollution Prevention Awareness Program is to foster the philosophy that prevention is superior to remediation. The goal of the program is to incorporate pollution prevention into the decisionmaking process at every level throughout the organization.

\subsection{TRAINING}

One of the most important elements of the WMPPAP is training. The goal of the training program will be to make each employee in the ER Program aware of the generation of uncontrolled waste, its impact on the site and the environment, and methods to reduce waste and prevent pollution.

Contractors and site users shall develop and implement an employee training program or adopt an existing program. These programs or plans shall be documented in contractor and site user implementation plans.

A waste minimization training session will be included in one of the ER Program quarterly waste minimization workshops. Training will involve a discussion on the definitions of waste minimization, a review of the regulations regarding waste minimization, and guidance on how to minimize waste. Waste minimization training will be revised to meet the quality assurance (QA) requirements as discussed in Sect. 9.4.

\subsection{EMPLOYEE ORIENTATION PROGRAM}

A WMPPAP orientation will be established and will be integrated into a general orientation program for all employees. The orientation program will be coordinated and conducted by the ER waste programs and the ER waste reduction manager. The orientation program will include the following elements.

- 'The need for, and benefits to be derived from, waste minimization and pollution prevention

- The contribution each employee can make to an improved working and living environment

- Management commitment to waste minimization and site waste minimization policy

- Overview of policy and regulations

- Improved operation practices for reducing waste generation

- Solicitation of waste minimization and pollution prevention ideas and the discussion of solutions to identified problems 


\subsection{ER SPECIALIZED TRAINING PROGRAM}

ER specialized training sessions on pollution prevention policy and procedures and waste minimization techniques will be tailored for management, line, and staff positions. The coordination and documentation of employee training and awareness are the responsibilities of the ER waste reduction manager with the assistance of the ER training officer. These sessions will be incorporated into the regularly scheduled training program. The adequacy of training procedures and of any special equipment needed to perform waste minimization functions will be evaluated annually by the ER waste reduction manager.

\subsection{PROCEDURES QUALIFICATION}

As part of QA, employees who coordinate, supervise, or handle wastes are required to be trained and examined on their knowledge of site standard operating procedures before performing work. Waste minimization will be incorporated into operating, administrative, and waste procedures requiring documentation using data sheets or forms. Training on waste minimization, therefore, will also be part of the QA procedures qualification process.

\subsection{PERFORMANCE EVALUATIONS}

Waste minimization goals, objectives, and accomplishments will be incorporated into annual evaluations of job performance for those persons who have waste minimization responsibilities.

\subsection{POLLUTION PREVENTION AWARENESS}

The Pollution Prevention Awareness Program required by DOE Order 5400.1 (ref. 1) has been incorporated with the Waste Minimization Program. The purpose of the Pollution Prevention Awareness Program is to foster the philosophy that prevention is superior to remediation. The goal of the program is to incorporate pollution prevention into the decisionmaking process at every level throughout ER.

The Pollution Prevention Awareness Program has the following objectives:

- Make employees aware of general environmental activities and hazards at the site and waste minimization program requirements, goals, and accomplishments.

- Inform employees of specific environmental issues.

- Train employees on their responsibilities in pollution prevention.

- Recognize employees for efforts to improve environmental conditions through pollution prevention.

- Publicize success stories.

The program consists of four elements: (1) pollution prevention awareness campaign, (2) awards and recognition, (3) information exchange, and (4) training. 
The ER pollution prevention awareness campaign will be conducted at least once each year. It will be developed by ER waste management. The campaign will make extensive use of site newsletters, seminars, bulletin boards, signs, and slogans to enhance employee awareness of and participation in pollution prevention at ER facilities.

The remaining elements of the Pollution Prevention Awareness Program are described in other sections of this plan. Incentive awards and recognition are discussed in Sect. 9.7. Information exchange is discussed in Chap. 12. Training has been discussed in Sects. 9.1 through 9.3.

Contractors and site users are required to develop and implement an Employee Awareness Program or adopt an existing employee awareness progran by April 30, 1992. Such programs or plans shall be updated to incorporate guidance and documented in contractor and user waste minimization and pollution prevention awareness implementation plans.

\subsection{INCENTIVE AWARDS AND RECOGNITION}

Contractors are required to implement an Employee Suggestion Award Program or adopt an existing program. Programs or plans shall be documented in contractor implementation plans. ER will encourage DOE-OR employees to submit waste minimization suggestions through the regular employee suggestion program. Award programs will be used to recognize individual and team waste minimization and pollution prevention achievements. 


\section{TRACKING AND REPORTING SYSTEMS}

The waste streams to be tracked are divided into seven major categories: RCRA waste, mixed RCRA waste, low-level radioactive waste, Toxic Substances Control Act (TSCA) waste, mixed TSCA waste, sanitary waste, and transuranic waste. The ER Program is presently in the investigation phase of its activities, and the rate of waste generation is reasonably low. Wastes from current operations include remnants from sampling activities, decontamination solutions, groundwater, solvents/oils, soil cuttings, concrete debris, contaminated protective clothing, trash, metal scrap, asbestos, and the sludges generated from RA and D\&D activities.

\subsection{TRACKING FROM POINT OF GENERATION TO POINT OF FINAL DELIVERY TO THE SITE WASTE MANAGEMENT ORGANIZATIONS}

Wastes generated by ER Program activities will be tracked by projecting waste generation estimates using a set of standard assumptions before the fiscal year and updating those estimates throughout the year as additional waste generation requirements are mandated or additional remedial activities are required. Actual wastes generated will be tracked and entered into a computerized tracking system. Actual waste generated versus waste generation estimates will be tracked to provide waste projection comparisons.

The computerized tracking system will track waste from point of generation to point of final delivery to the site waste management organizations. ER waste will be identified and tracked by the use of a waste generation number unique to ER. The system will collect data on input material, material usage, type of waste, volume, hazardous constituents, generating system, generation date, and other relevant information. The system will identify program resource requirements and report cost benefits realized from implementing waste reduction projects. The data collected by the system will be used for internal reporting and to meet external reporting requirements discussed below under federal and state reporting requirements.

\subsection{PROCUREMENT CONTROL SYSTEM}

Procedures for control and purchase of hazardous chemicals or other materials will be reviewed to determine whether improvements in those procedures will aid in achieving waste minimization goals. A system will be developed to track the purchase and usage of hazardous materials.

\subsection{PROGRAM ACTIVITY TRACKING}

A system will be developed to provide feedback on the progress of the WMPPAP, including the results of waste minimization technologies and other implemented waste minimization options. 


\subsection{FEDERAL AND STATE REPORTING REQUIREMENTS}

Tracking systems developed under this program will be designed to facilitate reporting waste minimization data and accomplishments to DOE, EPA, and appropriate state agencies in Tennessee, Kentucky, and Ohio. 


\section{QUALITY ASSURANCE}

Guidance $^{6}$ implementing DOE Order 5820.2A stresses the requirement and need for QA in conducting waste reduction activities. It indicates that waste reduction programs are required to "retain an appropriate level of documentation and accountability. The documentation of these programs should be designed to satisfy all requirements of the Waste Operations Quality Assurance Program at each field office."

\subsection{QA PROGRAM PLAN}

The proper documentation of waste minimization activities is critical to attaining an adequate level of confidence that the requirements of the DOE orders requiring minimization of waste are being met. A QA program plan will be developed for the WMPPAP as required for all programs by DOE Order $5700.6 \mathrm{~B}$ (ref. 7). The plan will specify documentation that will enable verification of data reported in annual and biennial reports, and it will ensure that the character of all wastes can be verified and traced to their source.

\subsection{QA TRAINING}

Contractors and users will ensure that waste minimization training is conducted and documented. As discussed in Sect. 9.4, the QA procedures qualification process will include training and qualification on waste minimization. 


\section{INFORMATION EXCHANGE AND OUTREACH}

All program staff are encouraged to make regular use of the EPA data bases and the Waste Information Network system for information exchange and outreach. The ER Program obtains lessons-learned information through participation in and/or access to the following.

- EPA waste minimization bulletin board and data base

- Pollution Information Exchange System

- Hazardous Waste Remedial Action Program technology transfer

- Workshops, symposia, and other meetings sponsored by EPA, DOE, other federal agencies, and the private sector

- Interfaces with the Energy Systems Waste Research and Development Program, CWMD, and emergency management support organizations; EPA; DOE; other federal agencies; and the private sector

- Periodicals, reports, and other publications

The waste reduction manager will monitor information made available by such sources as the EPA Pollution Prevention Information Clearinghouse and the Waste Minimization Technology Newsletter. The waste reduction manager will also interface with the DOE Waste Information Network system to access its Waste Minimization Bulletin Board and Regulatory Update. The waste reduction manager and other contractors and site users will exchange information during quarterly workshops and through hard-copy information exchange. This will include sharing information on new federally developed technology within the ER organization.

Participation in business, education, and government forums is also encouraged because they are designed to provide technical assistance and an opportunity to exchange waste minimization information. The ER waste reduction manager will play a pivotal role in the ER Program information exchange and outreach activities. 


\section{TECHNOLOGY TRANSFER}

DOE has established the Office of Technology Development for Applied Research, Development, Demonstration, Testing, and Evaluation (RDDT\&E), within the Office of Environmental Restoration and Waste Management. The functions of technology transfer, identification of RDDT\&E needs, and technology demonstration, testing, and evaluation within the Energy Systems ER Program are referred to as Technology Development and Applications (TD\&A).

The transfer of federally developed technology between laboratories and potential users is a contractual responsibility of DOE facilities and laboratories. Therefore, the TD\&A function is carried out by the Technical Integration Program in conjunction with the site ER programs. Activities involving technology transfer will be coordinated through this office, which has been designated to represent the ER Program on the Federal Laboratory Consortium for technology transfer. The Consortium promotes technology transfer through links to the public and private sectors and through support services such as training and assistance in implementing partnership opportunities (e.g., cooperative agreements and patent licensing). Opportunities for transfer of technologies specific to waste minimization programs may develop from information exchange systems, workshops, or topical conferences. The TD\&A manager will facilitate direct exchanges of process technology between facilities whenever possible, and the support services of the Federal Laboratory Consortium will be used where appropriate. Technology projects that are identified and implemented will be coordinated with the DOE Headquarters Office of Technology Development. 


\section{RESEARCH AND DEVELOPMENT}

Some options may require development work before they are implemented. The Energy Systems waste research and development (R\&D) organization is responsible for the planning, funding, and day-to-day management of technology demonstrations. Frequent and direct interaction with the ER TD\&A manager, who is matrixed to the site demonstration program managers, is required to effectively carry out these activities. Effective interactions will be maintained among Energy Systems technical staff, program offices, and sites in implementing demonstrations of new ER waste management technologies.

Proposals for R\&D should arise from waste assessments and evaluations of the waste minimization options. Some options may require development work before being implemented. The waste assessments may also identify process inefficiencies that offer the potential for significant waste reduction, but specific process modifications may require R\&D work first. Budget requests should include support for appropriate R\&D. Specific proposals for R\&D work will be coordinated through field offices and the Office of Technology Development at DOE Headquarters to ensure effective allocation of resources. 


\section{PROGRAM EVALUATION}

The WMPPAP will be evaluated annually once the overall program implementation is achieved. All major activities will be reviewed. The evaluation will document program achievements and identify potential areas for improvement. At a minimum, the plan will be updated every 3 years. efforts.

The following criteria will be used to demonstrate the effectiveness of waste minimization

- Number of programmatic goals achieved

- Number of numerical goals achieved

- Cost reductions identified

- Number of noncompliances cited

- Integration of new technologies

The WRSRs will address these criteria when evaluating the success of process or other changes to reduce waste volume or toxicity. An accurate assessment for each appropriate criterion will be provided in evaluating the success of each waste minimization option implemented.

The program evaluation information will be incorporated into reports submitted to DOE, EPA, and the state agencies and will contain current-year data, performance trends, forecasts, and measures used to gauge the performance of waste minimization activities. The evaluation report will be used to establish future waste minimization goals and program objectives. The report will also be used to determine changes to this plan. 


\section{REFERENCES}

1. U.S. Department of Energy, DOE Order 5400.1, "General Environmental Protection Program," November 9, 1988.

2. U.S. Department of Energy, DOE Order 5400.3, "Hazardous and Radioactive Mixed Waste Program," February 22, 1989.

3. U.S. Department of Energy, DOE Order 5820.2A, "Radioactive Waste Management," September 26, 1988.

4. Memorandum from John C. Tuck, Under Secretary of Energy; Peter N. Brush, Acting Assistant Secretary, Environment, Safety and Health; and Leo P Duffy, Director, Office of Environmental Restoration and Waste Management, to Distribution (all elements of the Department of Energy), "Waste Reduction Policy," June 27, 1990.

5. W. F. Furth, letter to R. G. Donnelly, G. G. Fee, W. R. Golliher, and H. Postma, "Waste Minimization Policy," May 21, 1986.

6. U.S. Department of Energy, Implementation Guidance for DOE Order 5820.2A, October 24, 1988.

7. U.S. Department of Energy, DOE Order 5700.6B, "Quality Assurance," September 23, 1986. 


\section{BIBLIOGRAPHY}

Office of Management and Budget, "Reporting Requirements in Connection with the Prevention, Control, and Abatement of Environmental Pollution of Existing Federal Facilities," OMB Circular No. A-106, Executive Office of the President, December 31, 1974.

State of Tennessee, House Bill 2217, Appendix A, "The Tennessee Hazardous Waste Reduction Act of 1990," July 1, 1990.

U.S. Congress, Resource Conservation and Recovery Act of 1986, Pub.L. 94-580, October 21, 1976, as amended by the Hazardous and Solid Waste Amendments Act of 1984, Pub.L. 98-616, Section. 1003, part b, November 9, 1984.

U.S. Department of Energy, Environmental Restoration and Waste Management Five-Year Plan, DOE/S-0070, 1989.

U.S. Department of Energy, "Waste Minimization Guidance for Process Waste Assessments," November 1990 (draft).

U.S. Department of Energy, "Waste Minimization Plan and Waste Reduction Reporting of DOE Hazardous, Radioactive, and Radioactive Mixed Wastes," Implementation Guidance for DOE Order 5400.1, March 1990.

U.S. Environmental Protection Agency, 40 Code of Federal Regulations Subchapter I, 1989.

U.S. Environmental Protection Agency, "Draft Guidance to Hazardous Waste Generators on the Elements of a Waste Minimization Program," 54 Federal Register 25056, 1989.

U.S. Environmental Protection Agency, EPA Proposed Policy Statement on Source Reduction and Recycling, 54 Federal Register 3845, 1989.

U.S. Environmental Protection Agency, Waste Minimization Opportunity Assessment Manual EPA/625/7-88/003, July 1989. 
Appendix A

WASTE MINIMIZATION AND POLLUTION PREVENTION AWARENESS PROGRAM BUDGET 


\begin{tabular}{|c|c|c|c|c|c|c|}
\hline \multirow{2}{*}{ Activity } & \multicolumn{5}{|c|}{ Funding in \$1000 per year } \\
\cline { 2 - 7 } & FY 1992 & FY 1993 & FY 1994 & FY 1995 & FY 1996 & $\begin{array}{c}\text { PERSONNEL } \\
\text { (FTE) }\end{array}$ \\
\hline PROGRAM PLANNING & 150 & 150 & 150 & 150 & 150 & 1.50 \\
\hline WASTE ASSESSMENTS & 450 & 450 & 450 & 450 & 450 & 3.00 \\
\hline $\begin{array}{c}\text { POLLUTION PREVENTION } \\
\text { AWARENESS }\end{array}$ & 50 & 50 & 50 & 50 & 50 & 0.50 \\
\hline TRAINING & 100 & 100 & 100 & 100 & 100 & 1.00 \\
\hline $\begin{array}{c}\text { CAPITAL EQUIPMENT } \\
\text { SUBCONTRACTOR }\end{array}$ & 200 & 200 & 100 & 100 & 100 & \\
\hline TOTAL & 950 & 1250 & 1150 & 850 & 850 & 6.00 \\
\hline
\end{tabular}


Appendix B

ENVIRONMENTAL RESTORATION PROGRAM WASTE MINIMIZATION POLICY 


\title{
ENVIRONMENTAL RESTORATION PROGRAM WASTE MINIMIZATION POLICY
}

\author{
Waste Minimization and Pollution Prevention Awareness Program
}

The Environmental Restoration (ER) Program, Martin Marietta Energy Systems, Inc., is committed to excellence and leadership in protecting the environment. In keeping with this policy, our objective is to reduce waste and emissions. We strive to minimize adverse impact on the air, water, and land through excellence in waste reduction. By successfully reducing waste at its source, we can achieve cost savings, increase operational efficiencies, improve the quality of our products and services, and maintain a safe and healthy workplace for our employees. The ER Program also promotes environmentally sound recycling, reuse, and reclamation of all waste streams.

ER environmental guidelines include the following.

- Environmental protection is everyone's responsibility. It is valued and displays commitment to the ER Program.

- Reducing and eliminating the generation of waste and emissions at the source is a primc consideration in research, process design, and plant operations. The ER Program is committed to identifying and implementing waste reduction opportunities through encouragement and involvement of all employees.

- All current programs related to waste minimization and control will be consolidated into a single, comprehensive program. A permanent ER waste reduction manager will be appointed to develop, guide, and oversee the implementation of the program.

- Technologies and methods that substitute nonhazardous materials and utilize other source reduction approaches will be given top priority in addressing all environmental issues.

- Protection of public health, safety, and the environment is a line responsibility and an important measure of employee performance. All employees are responsible for promoting the elements of this program to reduce waste. Waste reduction must be seen as the responsibility of all workers and managers involved in production, rather than just the responsibility of those who deal with pollution control and compliance.

- The ER Program seeks to demonstrate its corporate citizenship by adhering to all environmental regulations. We promote cooperation and coordination between industry, government, and the public toward the shared goal of reducing waste at its source and recycling in an environmentally sound manner.

Approved:

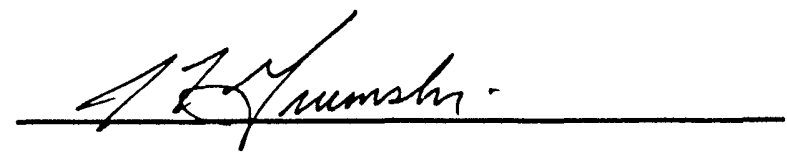

J. T. Grumski, Environmental Restoration Waste Management Program Manager

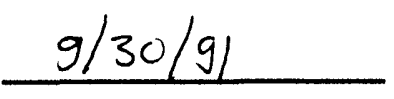

Date 
Appendix C

IMPLEMENTATION SCHEDULE FOR WASTE MINIMIZATION AND POLLUTION PREVENTION AWARENESS PROGRAM ACTIVITIES 


\section{Implementation Schedule for Waste Minimization and Pollution Prevention Awareness Program Activities}

\begin{tabular}{|c|c|c|}
\hline Program elements & $\begin{array}{l}\text { Organizational } \\
\text { responsibility }\end{array}$ & Schedule \\
\hline \multicolumn{3}{|l|}{ Budget } \\
\hline Complete first submission for FY 1992 & ER WM & $07 / 15 / 91$ \\
\hline Complete second submission for FY 1992 & ER WM & $09 / 15 / 91$ \\
\hline Conduct midyear review & ER WM & $05 / 15 / 92$ \\
\hline \multicolumn{3}{|l|}{ Employee achievement and incentives } \\
\hline Submit thank-you letters & ER WM & As received \\
\hline Submit projects for Award of Excellence & ER WM & Annually \\
\hline $\begin{array}{l}\text { Submit projects for ER Waste Minimization and } \\
\text { Pollution Prevention Awareness Award }\end{array}$ & ER WM & Annually \\
\hline Submit projects for Energy Systems Awards Night & ER WMI & Annually \\
\hline $\begin{array}{l}\text { Submit projects for DOE-OR Waste Minimization } \\
\text { Award }\end{array}$ & ER WM & Annually \\
\hline $\begin{array}{l}\text { Submit projects for DOE Weapons Complex } \\
\text { Award of Excellence }\end{array}$ & ER WM & Annually \\
\hline \multicolumn{3}{|l|}{ Employee awareness and training } \\
\hline $\begin{array}{l}\text { Complete ER awareness campaign development for } \\
\text { waste minimization and pollution prevention }\end{array}$ & ER WM & $\begin{array}{l}12 / 31 / 91 ; \\
\text { annually thereafter }\end{array}$ \\
\hline Publish newsletter & ER WM & $\begin{array}{l}i 2 / 31 / 91 ; \\
\text { quarterly thereafter }\end{array}$ \\
\hline Kick off awareness campaign & ER WM & $\begin{array}{l}02 / 15 / 92 ; \\
\text { annually thereafter }\end{array}$ \\
\hline $\begin{array}{l}\text { Develop ER waste minimization and pollution } \\
\text { awareness training }\end{array}$ & ER WM & $03 / 01 / 92$ \\
\hline Complete awareness campaign & ER WM & $\begin{array}{l}04 / 30 / 92 ; \\
\text { annually thereafter }\end{array}$ \\
\hline Initiate training of ER personnel & ER WM & $\begin{array}{l}04 / 15 / 92 ; \\
\text { annual refresher }\end{array}$ \\
\hline $\begin{array}{l}\text { Review performance objectives; include waste } \\
\text { minimization goals as measure of job performance } \\
\text { where applicable }\end{array}$ & ER WM & $\begin{array}{l}09 / 30 / 92 ; \\
\text { annually thereafter }\end{array}$ \\
\hline
\end{tabular}




\begin{tabular}{|c|c|c|}
\hline Program elements & $\begin{array}{c}\text { Organizational } \\
\text { responsibility }\end{array}$ & Schedule \\
\hline $\begin{array}{l}\text { Conduct training on waste minimization and } \\
\text { requirements for waste management personnel }\end{array}$ & ER WM & $\begin{array}{l}\text { Ongoing for new } \\
\text { employees; annual } \\
\text { refresher }\end{array}$ \\
\hline \multicolumn{3}{|l|}{ Information exchange } \\
\hline $\begin{array}{l}\text { Conduct the quarterly ER waste reduction } \\
\text { workshop }\end{array}$ & ER WM & Quarterly \\
\hline $\begin{array}{l}\text { Participate in the biannual DOE contractor waste } \\
\text { reduction workshop }\end{array}$ & ER WM & Biannually \\
\hline \multicolumn{3}{|l|}{ Management support } \\
\hline $\begin{array}{l}\text { Issue ER waste minimization and pollution } \\
\text { revention awareness policy statement }\end{array}$ & ER WM & $09 / 30 / 91$ \\
\hline $\begin{array}{l}\text { Conduct ER Program review briefings with } \\
\text { management }\end{array}$ & ER WM & Biannually \\
\hline \multicolumn{3}{|l|}{ Policies, procedures, and plans } \\
\hline Publish and distribute ER Program WMPPAP & ER WM & $09 / 30 / 91$ \\
\hline $\begin{array}{l}\text { Issue guidance to sites and contractors for } \\
\text { implementation plan }\end{array}$ & ER WM & $10 / 15 / 91$ \\
\hline $\begin{array}{l}\text { Review each plant's procedures for hazardous } \\
\text { chemical procurement }\end{array}$ & ER WM & $10 / 31 / 91$ \\
\hline Review each site's sampling procedures & ER WM & $11 / 31 / 92$ \\
\hline Review site and contractor implementation plans & ER WM & $02 / 15 / 92$ \\
\hline Review WMPPAP & ER WM & Annually \\
\hline Update WMPPAP & ER WM & $\begin{array}{l}\text { As needed (every } \\
3 \text { years minimum) }\end{array}$ \\
\hline \multicolumn{3}{|l|}{ Quality assurance } \\
\hline $\begin{array}{l}\text { Issue QA guidelines specific to waste minimization } \\
\text { and pollution prevention to sites and contractors }\end{array}$ & $\begin{array}{l}\text { ER WM; } \\
\text { ER QA }\end{array}$ & $03 / 31 / 92$ \\
\hline Implement waste minimization training module & $\begin{array}{l}\text { ER WM; } \\
\text { ER QA }\end{array}$ & $\begin{array}{l}\text { To be incorporated } \\
\text { in general waste } \\
\text { minimization } \\
\text { training }\end{array}$ \\
\hline \multicolumn{3}{|l|}{ Tracking and reporting systems } \\
\hline Develop and implement waste tracking system & ER WM & $02 / 28 / 92$ \\
\hline $\begin{array}{l}\text { Calculate reductions in hazardous, mixed, } \\
\text { radioactive, and solid waste }\end{array}$ & $\begin{array}{l}\text { WRSR; } \\
\text { ER WM }\end{array}$ & Annually \\
\hline
\end{tabular}




\begin{tabular}{|c|c|c|}
\hline Program elements & $\begin{array}{l}\text { Organizational } \\
\text { responsibility }\end{array}$ & Schedule \\
\hline Compile report data & ER WM & Annually \\
\hline Prepare ER annual waste reduction report & ER WM & Annually \\
\hline Submit report to DOE & ER WM & Annually \\
\hline Submit biennial waste reduction report to EPA & $\begin{array}{l}\text { ER WM; } \\
\text { CEP; CWMD }\end{array}$ & Annually \\
\hline Submit report to state of Tennessee & ER WM & As required \\
\hline \multicolumn{3}{|l|}{ Waste assessments, surveillances, and evaluations } \\
\hline $\begin{array}{l}\text { Identify all waste streams generated by ER by } \\
\text { waste type and category }\end{array}$ & $\begin{array}{l}\text { Site users and } \\
\text { contractors }\end{array}$ & 09/30/91 \\
\hline $\begin{array}{l}\text { Develop short-term strategies and reduction } \\
\text { techniques }\end{array}$ & ER WM & $09 / 30 / 91$ \\
\hline Develop waste assessment guidance for ER & ER WM & $10 / 30 / 91$ \\
\hline $\begin{array}{l}\text { Identify project teams to conduct waste } \\
\text { assessments for ER }\end{array}$ & TBD & $11 / 15 / 91$ \\
\hline Issue waste assessment guidance & ER WM & $12 / 30 / 91$ \\
\hline Submit waste assessment schedules to ER WM & Project teams & $01 / 15 / 92$ \\
\hline Initiate waste assessments & Project teams & $01 / 30 / 92$ \\
\hline Develop program evaluation guidance & ER WM & $07 / 30 / 92$ \\
\hline Complete $20 \%$ of waste assessments & Project teams & $12 / 30 / 92$ \\
\hline Complete $40 \%$ of waste assessments & Project teams & $12 / 30 / 93$ \\
\hline Complete $60 \%$ of waste assessments & Project teams & $12 / 30 / 94$ \\
\hline Complete $80 \%$ of waste assessments & Project teams & $12 / 30 / 95$ \\
\hline Complete $100 \%$ of waste assessments & Project teams & $06 / 30 / 96$ \\
\hline Conduct review of waste assessments & ER WM & Ongoing \\
\hline $\begin{array}{l}\text { Conduct surveillance of contractors and user } \\
\text { operations }\end{array}$ & ER WM & Quarterly \\
\hline Develop waste minimization options & ER WM & Annually \\
\hline Screen waste minimization options & ER WM & Annually \\
\hline Evaluate waste minimization options & ER WM & Annually \\
\hline Rank and prioritize waste minimization options & ER WM & Annually \\
\hline Complete report on waste minimization options & ER WM & Annually \\
\hline Implement waste minimization options & ER WM & Annually \\
\hline Complete program evaluation & ER WM & Annually \\
\hline
\end{tabular}




\begin{tabular}{|c|c|c|}
\hline Program elements & $\begin{array}{l}\text { Organizational } \\
\text { responsibility }\end{array}$ & Schedule \\
\hline $\begin{array}{l}\text { Complete report to ER and D\&D Division } \\
\text { directors }\end{array}$ & ER WM & Annually \\
\hline Conduct surveillance of waste generator operations & $\begin{array}{l}\text { Site users and } \\
\text { contractors }\end{array}$ & $\begin{array}{l}\text { To be scheduled in } \\
\text { implementation } \\
\text { plans }\end{array}$ \\
\hline \multicolumn{3}{|l|}{ Waste characterization } \\
\hline $\begin{array}{l}\text { Issue guidance to characterize waste streams from } \\
\text { baseline to determine physical, chemical, and } \\
\text { radiological properties }\end{array}$ & ER WM & $03 / 01 / 92$ \\
\hline \multicolumn{3}{|l|}{ Technology transfer } \\
\hline $\begin{array}{l}\text { Summarize existing technoiogies for waste } \\
\text { treatment alternatives and identify new } \\
\text { technologies }\end{array}$ & ER WM & $\begin{array}{l}12 / 31 / 92 ; \text { annually } \\
\text { thereafter }\end{array}$ \\
\hline $\begin{array}{l}\text { Develop and implement techniques to ensure that } \\
\text { excess supplies of hazardous chemicals do not } \\
\text { increase }\end{array}$ & ER WM & $\begin{array}{l}\text { To be scheduled in } \\
\text { implementation } \\
\text { plans }\end{array}$ \\
\hline $\begin{array}{l}\text { Review maintenance programs for opportunities to } \\
\text { reduce waste }\end{array}$ & $\begin{array}{l}\text { Site users and } \\
\text { contractors }\end{array}$ & $\begin{array}{l}\text { To be scheduled in } \\
\text { implementation } \\
\text { plans }\end{array}$ \\
\hline \multicolumn{3}{|l|}{ Waste stream goals } \\
\hline Obtain waste generation rate forecasts for ER & ER WM & $08 / 31 / 91$ \\
\hline Evaluate the feasibility of paper recycling in ER & ER WM & $09 / 30 / 91$ \\
\hline Establish waste baseline for ER Program activities & ER WM & $10 / 31 / 91$ \\
\hline Implement paper recycling in ER & $\begin{array}{l}\text { Site users and } \\
\text { contractors }\end{array}$ & $12 / 30 / 91$ \\
\hline $\begin{array}{l}\text { Develop numerical goals for the ER waste } \\
\text { reduction program }\end{array}$ & ER WM & $\begin{array}{l}09 / 01 / 92 \text {; annually } \\
\text { thereafter }\end{array}$ \\
\hline $\begin{array}{l}\text { Review and approve numerical goals for ER waste } \\
\text { reduction program }\end{array}$ & CEP/CWMD & $\begin{array}{l}\text { TBD; annually } \\
\text { thereafter }\end{array}$ \\
\hline $\begin{array}{l}\text { Issue ER Program numerical goals; display and } \\
\text { track against the established baseline }\end{array}$ & ER WM & TBD; ongoing \\
\hline
\end{tabular}

\section{Acronyms}

\begin{tabular}{|c|c|c|c|}
\hline DOE & Department of Energy & QA & Quality Assurance \\
\hline DOE-OR & DOE Field Office, Oak Ridge & TDB & to be determined \\
\hline CEP & $\begin{array}{l}\text { Compliance Evaluations and Policy } \\
\text { (Division) }\end{array}$ & $\begin{array}{l}\text { WM } \\
\text { WMPPAP }\end{array}$ & $\begin{array}{l}\text { waste management } \\
\text { Waste Minimization and Pollution }\end{array}$ \\
\hline $\begin{array}{l}\text { CWMD } \\
\text { ER }\end{array}$ & $\begin{array}{l}\text { Central Waste Management Division } \\
\text { Environmental Restoration }\end{array}$ & WRSR & $\begin{array}{l}\text { Prevention Awareness Plan } \\
\text { waste reduction site representative }\end{array}$ \\
\hline
\end{tabular}


Appendix D

ORGANIZATIONAL CHART 
ORGANIZATIONAL CHART

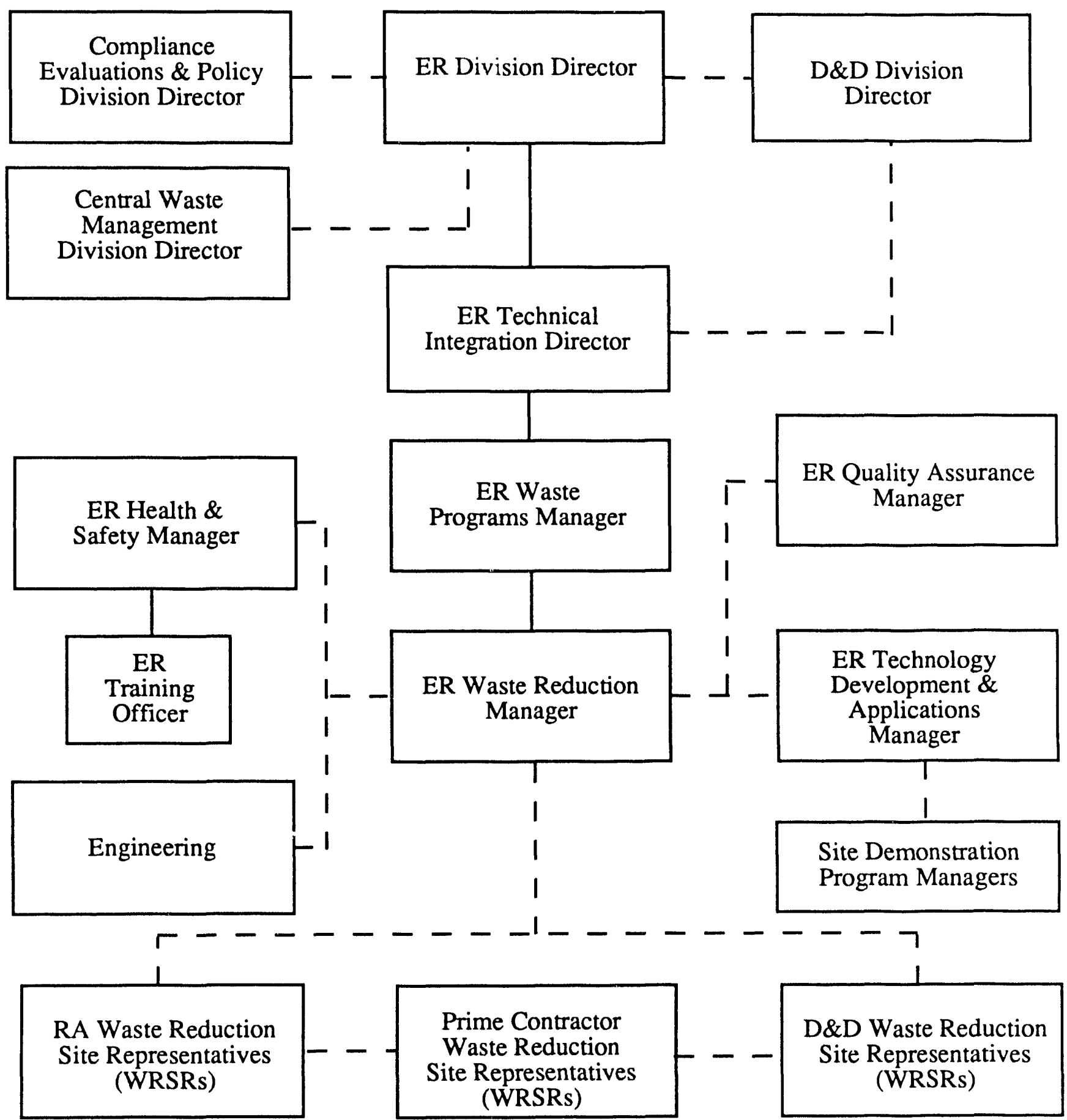




\section{DISTRIBUTION}

1. M. L. Ambrose

2. J. K. Bailey

3. B. O. Barritt

4. L. D. Bates

5. J. Betschart

6. S. C. Bieniek

7. V. J. Brumback

8. R. K. Dierolf, Jr.

9. N. W. Durfee/L. V. Asplund

10. G. E. Butterworth III

11. T. W. Burwinkle

12. K. M. Cash

13. C. Clark

14. K W. Cook

15. D. G. Cope

16. D. L. Daugherty

17. R. K. Dierolf, Jr.

18. M. F. P. DeLozier

19. C. H. Estes III

20. C. J. Ford

21. A. E. Freels

22. C. E. Frye

23. C. D. Goins

24. J. T. Grumski

25. D. B. Gunter

26. C. J. Hammonds

27. E. S. Harrington

28. H. E. Harper

29. J. L. Haymore

30. J. A. Hedges

31. J. E. Heiskell, Jr.

32. K. G. Kahl

33. C. M. Kendrick

34. B. L. Kimmel
35. E. A. Krispin

36. S. M. Leone

37. L. E. May

38. L. J. Mezga

39. S. R. Michaud

40. J. Q. Miller

41. M. E. Mitchell

42. T. E. Myrick

43-44. P. T. Owen

45. G. A. Person

46. B. E. Phifer, Jr.

47. G. A. Plante

48. G. E. Rymer

49. T. F Scanlan

50. R. M. Schultz

51. R. D. Scott

52. R. H. Snyder

53. L. H. Stinton

54. J. S. Suffern

55. D. W. Swindle

56. G. L. Underberg

57. J. S. Watson

58. A. E. Walzer

59. S. H. Welch

60. D. C. White

61. R. K. White

62. H. D. Whitehead

63. M. L. Whitehead

64. H. D. Wooten

65. Central Research Library

66. Y-12 Technical Library

67-71. ER Document Management Center

72-73. ORNL Laboratory Records

74. Office of Assistant Manager for Energy Research and Development, DOE Field Office, Oak Ridge, P.O. Box 2001, Oak Ridge, Tennessee 37831-8600

75. P. H. Edmonds, Radian Corporation, 120 South Jefferson Circle, Oak Ridge, TN 37830

76. T. E. Gangwer, Science Applications International Corporation, P.O. Box 350, Oak Ridge, TN 37831-0350

77. C. S. Gist, DOE Field Office, Oak Ridge, P.O. Box 2001, Oak Ridge, Tennessee 37831-8541

78-81. W. E. Murphie, Department of Energy, Office of Environmental Restoration, Eastern Area D\&D Branch, EM-423 (GTN), Washington, DC 20545

82-83. S. S. Perkins, DOE Field Office, Oak Ridge, Information Resource Center, 105 Broadway, Oak Ridge, TN 37830

84. E. J. Powell, DOE Field Office, Oak Ridge, P.O. Box 2001, Oak Ridge, Tennessee 378318541

85. R. C. Sleeman, DOE Field Office, Oak Ridge, P.O. Box 2001, Oak Ridge, Tennessee 378318541

86-87. Office of Scientific and Technical Information, P.O. Box 62, Oak Ridge, TN 37831 


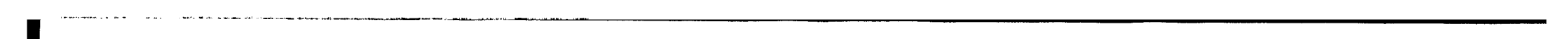

$=$ 